\section{Etiske utfordringer i prehospital virksomhet}

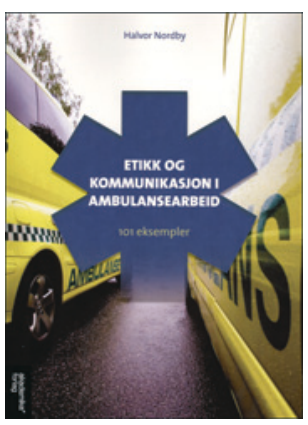

Halvor Nordby

Etikk og kommunikasjon i ambulansearbeid

101 eksempler. 167 s, ill. Trondheim:

Akademika forlag, 2014. Pris NOK 199

ISBN 978-82-321-0344-7
Boken er ment som en samling av etiske problemstillinger til bruk i ambulanseutdanninger, både på fagbrevs- og «paramedic»-nivå. Den har et innledende kapittel på 20 sider med forfatterens syn på fremgangsmåter til å håndtere etiske problemstillinger i ambulansetjenesten. Etter dette følger ti kapitler med i alt 101 eksempler på vanskelige situasjoner der ambulansepersonell settes i valgsituasjoner i prehospitalt arbeid, situasjoner der det ikke finnes én rett løsning, men flere handlingsalternativer. Problemstillingene er delt i «etiske dilemmaer» om autonomi, medbestemmelse, livskvalitet, spesielle og kriserammede pasientgrupper og «kommunikasjonsutfordringer» om språk, konflikter, formidling av informasjon, intern og ekstern samhandling.

Eksemplene er fra studenter i forfatterens arbeid med ambulanseutdanninger, og skal være reelle, men tilstrekkelig anonymiserte og stiliserte til å ha rendyrket ett hovedfokus. Hvert eksempel kommenteres av forfatteren og fyller én bokside, verken mer eller mindre.

Kapittel 1 er relativt tungt og av typen «om oss, ikke til oss» i forhold til den oppgitte målgruppen. Det egner seg bedre til den som planlegger undervisning.

Eksemplene varierer noe i syn på ambulansepersonells selvstendighet, der enkelte forutsetter tett kontakt med ansvarlig lege, mens andre bygger på uvanlig stor grad av delegering og autonomi. De fleste av kommentarene er greie, mens noen er unødvendig teoritunge og vil være vanskelig å bruke uten lengre forberedelse. Innledningsvis er teksten noe tunglest pga. mange referanser og oppramsing av forfattere og årstall. Det er svært hyppig referert til forfatters egne publikasjoner, mens referanser til tidsskriftartikler ikke er tilstrekkelig utfyllende til at man kan finne artiklene. En liste med anbefalt lesing ordnet tematisk hadde gjort større nytte.

Boken gir mange gode innspill til å ta opp utfordringer i prehospitalt arbeid som ellers kan være vanskelig å sette ord på. Utbyttet er nok mindre ved selvstudium, men bør kunne bli stort ved planlagt arbeid med grupper, som fagmøter, temakvelder, basesamlinger og planlagt undervisning, både i grunn- og videreutdanning, men ikke minst for praktisk arbeidende ambulansepersonell, luftambulanse- og redningshelikopterbesetninger, redningstjenester, brann og politi. Vi anbefaler den som en god åpning til et tema som ellers lett blir teoretisk og abstrakt.

\section{Oversiktlig om fysikalsk funksjonsundersøkelse}

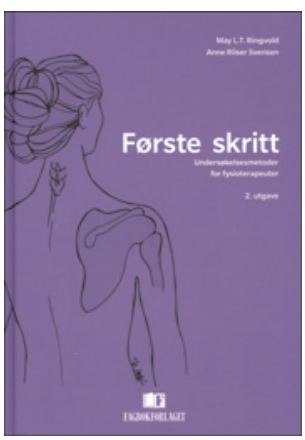

May L.T. Ringvold, Anne Riiser Svensen Første skritt

Unders $\varnothing$ kelsesmetoder for fysioterapeuter.

2 utg. 289 s, tab, ill. Bergen: Fagbokforlaget, 2014. Pris NOK 389

ISBN 978-82-450-1550-8

Boken er rettet mot fysioterapistudenter, deres lærere og andre interesserte og omfatter 15 kapitler. Innledningsvis gis en innføring i fysioterapeutisk undersøkelsesmetode. Deretter gjennomgås kroppsområdene i de påfølgende kapitlene. Beinlengde omtales i et eget kapittel, og det gjør også vinkelmålinger. I de tre siste kapitlene presenteres pasientkasuistikker.

Språket er folkelig og lettlest. Det er gode illustrasjoner av de anatomiske forholdene i de enkelte ledd. Hovedprinsipper for testing av muskler mv. er fremhevet i tabeller. Det gjør den lettere å bruke til oppslag.

Forfatterne gjennomgår systematisk og lettfattelig anatomiske og biomekaniske forhold samt topografisk palpasjon av det enkelte ledd og kroppsområde. De presenterer også de vanligste problemene og sykdommene samt funksjonsundersøkelse innenfor hvert kroppsområde. Hofte, kne, ankel og fot, skulder og skulderbue, albue, underarm og hånd, lumbalcolumna, torakalcolumna, cervikalcolumna og kjeve er dekket. En del viktige tilstander som gir opphav til problemer er også omtalt, men her er nok systematikken og kunnskapen svakere. Forfatterne kunne kanskje med hell valgt å detaljere funksjonsundersøkelsen ytterligere og ha en mer overordnet presentasjon av de underliggende patologiske forholdene.

Det innledende kapitlet er det svakeste. Her forsøker forfatterne å presentere noen viktige temaer. De spenner imidlertid fra ICFklassifikasjonssystemet (International Classification of Functioning, Disability and Health) til elementer i undersøkelsen og sammensatte lidelser. En mer enhetlig introduksjon til det undersøkelsesrettede fokuset ville vært formålstjenlig. Her mangler en teoretisk introduksjon til funksjonsundersøkelse og testing samt en kort introduksjon av kunnskapsbasert praksis.

Kasuistikkene er velegnet til å understreke viktige elementer i undersøkelsene og de praktisk kliniske konsekvensene. Særlig synes kapitlet om et overtråkk å gi en uttømmende illustrasjon av den diagnostiske tilnærmingen.

Alt $\mathrm{i}$ alt kan boken anbefales som innføring i undersøkelse av bevegelsesapparatet for fysioterapistudenter og andre interesserte.

\section{Cecilie Røe}

Avdelingsoverlege, Avdeling for fysikalsk medisin og rehabilitering Oslo universitetssykehus

Sigurd Wisborg Blix

Ambulansearbeider, Prehospital klinikk, Kirkenes

Finnmarkssykehuset

Torben Wisborg

Anestesilege, Akuttmedisinsk avdeling, Klinikk Hammerfest

Finnmarkssykehuset 